\title{
Analysis of Factors Affecting Performance of Vietnamese Commercial Banks: Testing SCP and ES Hypotheses
}

\author{
PHAN THU HIỀN \\ University of Economic HCMC \\ Email :phanthuhien@ueh.edu.vn \\ PHAN TH!̣ MỸ HẠNH \\ University of Finance and Marketing \\ Email : phanmyhanhnt@yahoo.com.vn
}

\section{ARTICLE INFO}

Article history:

Received:

June 17, 2013

Received in revised form

Sep. 20, 2013

Accepted:

Dec. 31,2013

Keywords:

influential factors, market structure, commercial banks, business

performance, ES, SCP.

\section{ABSTRACT}

The research aims at analyzing factors impacting on performance of Vietnamese commercial banks in the years 2005-2012. The authors test SCP (structure-conduct-performance) and ES (efficient structure) paradigms for factors affecting return ratios of banks. The results show that it is market concentration instead of market share that has positive effects on bank performance as shown in their return on average assets (ROAA) and return on average equity assets (ROAE). Additionally, bank size, ownership, ratio of deposit to total asset and inflation rate also produce effects on performance of commercial banks in Vietnam. These findings allow authors to offer some measures to support a sustainable development for Vietnamese commercial banks. 


\section{INTRODUCTION}

Banking system always plays an important role in economic stability, and development of a country and its network of branches is considered as arteries of an economy. Thus, stable and healthy activities of a banking system will support a sustainable development for the economy.

Many Vietnamese commercial banks witnessed falls in their profits (Hàn \& Ngọc, 2012) and rises in their bad debts (Thanh \& Bạch, 2013) after the financial crisis and the global economic recession in the years 2007-2009. This situation badly affected performance of banks as well as Vietnam's economic stability. Analyzing impacts of influential factors on profit of Vietnamese commercial banks, therefore, has become an urgent matter. This research will test SCP (structure-conductperformance) and ES (efficient structure) models to find factors that have strong effects on banking profit at present, thereby suggesting some solutions or policy implications to support a sustainable development for Vietnamese commercial banks.

\section{MARKET CONCENTRATION AND BUSINESS PERFORMANCE}

\section{a. SCP and ES Hypotheses:}

To analyze factors affecting performance of Vietnamese commercial banks, empirical researches often test two competing hypotheses, SCP and ES.

SCP hypothesis proposes a positive correlation between market concentration and a firm's business performance. The firms in more concentrated markets will earn higher profits than those in less concentrated ones, due to the exclusive profitability and the collusion between the firms of the industry (Lloyd-Williams et al., 1994). Many empirical studies of banks' performance also agree with this hypothesis such as Rose \& Fraser (1976), Heggestad \& Mingo (1977), Spellman (1981), Rhoades (1982), Podenda (1986), Lloyd-Williams et al. (1994), Molyneux \& Forbes (1995), Mendes \& Rebelo (2003), Samad (2005), and Bhatti \& Hussain (2010). In the research of Mendes \& Rebelo (2003) and Sathye (2005), concentration ratio (CR) of the four banks that have the greatest market shares (four-firm concentrated ratio CR4), is the significant coefficient to test the models. 
Contrarily, ES hypothesis proposes that concentration ratio does not affect a firm's performance, and the concentrated market firms derive higher profits due to advantages in economies of scale and their outstandingly efficient performance. The firms with the most efficient performance will obtain a large market share and profit. This hypothesis is also agreed and supported by Demsetz (1973), McGee (1974), Peltzman (1977), and Brozen (1982).

Smirlock et al. (1984), Smirlock (1985), and Evanoff \& Fortier (1988), in addition, examine data of the US banking system and posit that the performance of a particular bank is a factor affecting its profit. Several empirical researches, such as Maudos (1998), Sathye (2005) and Samad (2007) agree with this hypothesis.

\section{b. Methodology:}

In order to analyze impacts of factors on return ratios of commercial banks, authors use unbalanced panel data of 28 Vietnamese commercial banks in the period 2005-2012 comprising four state-owned commercial banks (Agribank, BIDV, Vietcombank and Vietinbank), and 24 joint-stock ones. Indicators of banks such as ROAA, ROAE, total assets, total bank deposit and total loan are collected from Fitch IBCA's Bankscope Database. Meanwhile, data on ownership and total deposit in the Vietnamese commercial banks are collected from the SBV annual reports, and data on inflation rate are from the IMF.

Based on researches by Molyneux \& Forbes (1995), Maudos (1998), and Bhatti \& Hussain (2010), authors employ the following model:

$$
\Pi=\beta_{0}+\beta_{1} \mathrm{CR}+\beta_{2} \mathrm{MS}+\Sigma \beta_{\mathrm{i}} \mathrm{Z}_{\mathrm{i}}(\mathbf{1})
$$

where:

$\Pi$ : dependent variable measuring return ratio considered as the bank performance.

CR: independent variable measuring the market concentration and formed by the ratio of total deposit of the three or four largest banks to that of the banking system; or total loan of the three or four largest banks to that of the banking system; and the ratio of total assets of the three or four largest banks to those of the banking system.

MS: independent variable showing the market share of a firm. 
Z: other variables representing characteristics of the surveyed firm or market. For example, the size of a bank (measured by its total assets), credit risk (measured by the ratio of bank loan to bank total assets), liquidity risk (the ratio of bank loan to total deposit), bank's ownership (using dummy variables for government and private ownership), and macroeconomic factors (GDP and inflation).

If $\beta_{1}$ is greater than zero and $\beta_{2}$ is zero, the SCP hypothesis is supported, and if $\beta_{1}$ is zero and $\beta_{2}$ is greater than zero, the ES hypothesis is supported.

In this paper, the following regression model is used to test the two hypotheses for the system of Vietnamese commercial banks:

$\Pi=\beta_{0}+\beta_{1}$ CR4 $4+\beta_{2}$ MS $_{\mathrm{i}}+\beta_{3}$ LNASS $_{\mathrm{i}}+\beta_{4}$ DEASS $_{\mathrm{i}}+\beta_{5}$ LOASS $_{\mathrm{i}}+\beta_{6}$ OWNERS $_{\mathrm{i}}+\beta_{7}$ INF (2)

where:

II: dependent variable measuring the bank business performance by the return ratios, or ROAA and ROAE in this research to be precise.

$\Pi_{\mathrm{A}}=$ ROAA (Return on Average Assets ratio).

$\Pi_{\mathrm{E}}=\mathrm{ROAE}$ (Return on Average Equity Assets ratio).

Thus, model (2) can be represented as follows:

ROAA $=\beta_{0}+\beta_{1}$ CR4DE $+\beta_{2}$ MS $_{i}+\beta_{3}$ LNASS $_{i}+\beta_{4}$ DEASS $_{i}+\beta_{5}$ LOASS $_{i}+\beta_{6}$ OWNERS $_{\mathrm{i}}+\beta_{7}$ INF (3)

ROAE $=\beta_{0}+\beta_{1}$ CR4DE $+\beta_{2}$ MS $_{\mathrm{i}}+\beta_{3}$ LNASS $_{\mathrm{i}}+\beta_{4}$ DEASS $_{\mathrm{i}}+\beta_{5}$ LOASS $_{\mathrm{i}}+\beta_{6}$ OWNERS $_{i}+\beta_{7}$ INF (4)

CR4DE: a coefficient measuring the market concentration of the four largest banks (CR4). In this paper, CR4 is measured by:

CR4DE = total deposit of the four largest banks/ total deposit of commercial banks

The four largest banks in terms of deposit are Agribank, Vietcombank, Vietinbank and BIDV.

$\beta_{1}$ : the coefficient of CR4DE. It is assumed that $\beta_{1}$ is greater than zero and plays an important role in the SCP hypothesis.

$M S_{i}$ : the market share of the $i^{\text {th }}$ bank, measured by: 
$M S_{i}=$ Total deposit of the $i^{\text {th }}$ bank/ Total deposit of commercial banks

$\beta_{2}$ : the coefficient of $M S_{i}$. It is supposed that $\beta_{2}$ is greater than zero and plays an important role in the ES hypothesis.

Table 1: Other Variables in the Model

\begin{tabular}{|c|c|c|c|}
\hline Variables & Description & $\begin{array}{l}\text { Theoretical and } \\
\text { empirical basis }\end{array}$ & $\begin{array}{l}\text { Predicted } \\
\text { impact }\end{array}$ \\
\hline LNASS $_{\mathrm{i}}$ & $\begin{array}{l}\text { It represents the size of the } i^{\text {th }} \text { bank } \\
\text { measured by the logarithm of total } \\
\text { assets of the } i^{\text {th }} \text { bank. }\end{array}$ & Bhatti \& Hussain (2010) & + \\
\hline DEASS $_{\mathrm{i}}$ & $\begin{array}{l}\text { Considered as a variable for } \\
\text { liquidity risk of the bank, this is the } \\
\text { ratio of bank deposit to total assets } \\
\text { of the } \mathrm{i}^{\text {th }} \text { bank. }\end{array}$ & $\begin{array}{l}\text { García-Herrero et al. } \\
(2009)\end{array}$ & $+/-$ \\
\hline LOASS $_{\mathrm{i}}$ & $\begin{array}{l}\text { The ratio of bank loan to total } \\
\text { assets of the } \mathrm{i}^{\text {th }} \text { bank is considered } \\
\text { as a measure of the bank credit } \\
\text { risk. }\end{array}$ & $\begin{array}{l}\text { Maudos (1998), Sathye } \\
(2005)\end{array}$ & + \\
\hline OWNERS $_{\mathrm{i}}$ & $\begin{array}{l}\text { This dummy variable represents } \\
\text { ownership of the } i^{\text {th }} \text { bank. It is } \\
\text { assumed that: } \\
\text { OWNERS }_{\mathrm{i}}=1 \text { for joint stock } \\
\text { commercial bank } \\
\text { OWNERS }_{\mathrm{i}}=0 \text { for state-owned } \\
\text { commercial bank }\end{array}$ & $\begin{array}{l}\text { Samad (2007); Molyneux } \\
\text { \& Forbes (1995) }\end{array}$ & + \\
\hline INF & Annual inflation rate & Mirzaei et al. (2013) & - \\
\hline
\end{tabular}

\section{RESULTS AND DISCUSSIONS}

The results of the Breusch-Pagan and Hausman tests presented in Table 2 show that the random effect model (REM) is more suitable than the fixed effect model (FEM) or the ordinary least squares method (OLS). In both models (3) and (4), hence, authors use REM to analyze panel data, and the regression results are reported in Table 3 and Table 4. 
Table 2: Breusch-Pagan Test and Hausman Test

\begin{tabular}{cl}
\hline \multicolumn{1}{c}{ Comparison } & \multicolumn{1}{c}{ Results } \\
\hline \multirow{2}{*}{ OLS and REM } & p value of Breusch-Pagan test \\
& - ROAA: 0.0000 \\
& - ROAE: 0.0223 \\
& p value of Hausman test \\
FEM and REM & - ROAA: 0.8399 \\
& - ROAE: 0.1964 \\
\hline
\end{tabular}

Source: Authors' calculations

Table 3: Regression Results - with ROAA

\begin{tabular}{lcccc}
\hline \multicolumn{1}{c}{ ROAA } & Coefficient & Standard error & $\mathbf{z}$ & $\mathbf{P}>|\mathbf{z}|$ \\
\hline CR4DE & 1.333 & 0.738 & 1.81 & $0.071^{*}$ \\
MS & 0.481 & 1.717 & 0.28 & 0.779 \\
LNASS & 0.071 & 0.086 & 0.83 & 0.408 \\
DEASS & -2.301 & 0.598 & -3.85 & $0.000^{* * *}$ \\
LOASS & 0.233 & 0.384 & 0.61 & 0.545 \\
OWNERS & 0.720 & 0.218 & 3.31 & $0.001^{* * *}$ \\
INF & -0.015 & 0.007 & -2.31 & $0.021^{* *}$ \\
cons & 0.497 & 1.818 & 0.27 & 0.785 \\
\hline Observing & 219 & & & \\
$\mathrm{R}^{2}$ & 0.221 & & & \\
\hline
\end{tabular}

Notes: $* * * \mathrm{p}<0.01 ; * * \mathrm{p}<0.05 ; * \mathrm{p}<0.10$

Source: Authors' calculations

Table 4: Regression Results - with ROAE

\begin{tabular}{lcccc}
\hline \multicolumn{1}{c}{ ROAE } & Coefficient & Standard error & $\mathbf{z}$ & $\mathbf{P}>|\mathbf{z}|$ \\
\hline CR4DE & 42.305 & 10.027 & 4.22 & $0.000 * * *$ \\
MS & 14.557 & 22.729 & 0.64 & 0.522 \\
LNASS & 3.687 & 1.155 & 3.19 & $0.001 * * *$ \\
DEASS & -1.787 & 8.401 & -0.21 & 0.832 \\
LOASS & -4.915 & 5.222 & -0.94 & 0.347
\end{tabular}




\begin{tabular}{lcccc} 
OWNERS & 4.683 & 2.733 & 1.71 & $0.087 *$ \\
INF & -0.169 & 0.096 & -1.76 & $0.078^{*}$ \\
cons & -76.363 & 24.408 & -3.13 & $0.002 * * *$ \\
\hline Obs. & 219 & & & \\
$\mathrm{R}^{2}$ & 0.235 & & & \\
\hline
\end{tabular}

Notes: $* * * \mathrm{p}<0.01 ; * * \mathrm{p}<0.05 ; * \mathrm{p}<0.10$

Source: Authors' calculations

- At the significance level of $1 \%$ and $10 \%$, the $\beta$ coefficient of the variable CR4DE is positive in both models [1.333 in (3) and 42.305 in (4)], which shows the positive effects of the market concentration on ROAA an ROAE of commercial banks. This result supports the SCP hypothesis because it proposes that in an imperfect competition market where a group of major banks controls most bank deposits, or in other words, the market concentration is higher, these banks could gain greater profits and higher lending rates with lower deposit rates due to the collusion between them, which leads to their better financial performance. In the period 2005-2012, most sources of bank deposits were controlled by four state-owned commercial banks: Agribank, Vietcombank, Vietinbank and BIDV. Due to monopolistic benefits, banks in highly concentrated markets could obtain higher profitability ratios and better performance because of the collusion for their common benefits.

- In model (4), the positive coefficient of the variable LNASS at a significance level of $1 \%$ implies that the larger the bank size, the higher the ROAE ratio. This result supports the study by Bhatti \& Hussain (2010) which maintains that the larger banks have wider investment portfolios and better investment diversification.

According to theories of investment portfolio, if a firm keeps a great portfolio, it can diversify the risk and gain higher profits. In Vietnam, therefore, the larger size can allow banks to expand their branches to attract more deposits and develop lending services for more profits.

According to Article 6 of Decision 13/2008/QĐ-NHNN, existing branches of a bank should have a chartered capital greater than VND100 billion multiplied by number of existing and future branches in Hà Nội and HCMC plus VND50 billion multiplied by number of existing and future branches in other provinces than HCMC 
and Hà Nội. Thus, the larger the size of banks, the higher their ability to expand their business. The expansion provides customers with more convenient banking services and helps banks gain more profits from even traditional services that are still main sources of profits for Vietnamese commercial banks.

Additionally, greater assets allow banks to invest in new technologies and develop new services, thereby gaining non-interest incomes such as service fees, bank charges and commission. Such new incomes can help banks reduce risk during periods of instability that affect badly traditional banking operations. Moreover, the larger size also helps improve competitiveness and return ratio of the banks.

- The two positive values $(0.720$ and 4.683$)$ of the $\beta$ coefficient of the variable OWNERS at significance level of $1 \%$ and $10 \%$ show positive impacts of ownership on the banks' return ratios. This result reflects a difference in business performance between joint-stock and state-owned commercial banks. In other words, joint-stock commercial banks usually obtain better performance than state-owned ones do because their management is more dynamic and flexible, their banking technologies are modernized faster, and they are under no obligation to finance state-owned firms. Poor performance of state-owned firms is a burden to state-owned commercial banks and reduces their business performance (Trương 2010).

- The negative coefficients of INF at significance levels of 5\% and 10\% show that higher inflation rates make the banks' ROAA and ROAE fall. This result is compliant with findings by many researches on impacts of inflation on the banks' return ratios (Boyd et al., 2001; and Mirzaei, 2013). According to Phạm (2008), high inflation in Vietnam is one of the reasons for the interest rate competition among commercial banks to attract deposits and retain customers. Banks can offer deposit rate equal to lending one, leading to a danger of huge losses in lending services. An increase in deposit rate also leads to a rise in lending rate, which makes it difficult for the banks to find borrowers. This situation reduces the profits because interest payments constitute the main source of income for Vietnamese commercial banks, accounting for $70 \%-90 \%$ of their total incomes.

- In model (3), the coefficient of the variable DEASS is -2.301 at the significance level of $1 \%$, implying that the ROAA falls when the DEASS rises. In the years 20052012, Vietnam's banking system faced a keen interest rate competition and was 
affected by the global financial crisis and economic recession; therefore, the banks had to offer high deposit rate extensively, which reduced their profits.

- In both models, although the coefficient of the variable MS is positive, it is not statistically significant. This result, hence, does not support the ES hypothesis because it does not prove that low cost of efficient banks will improve their competitiveness and market share, thereby enhancing their performance. In other words, this result supports the SCP hypothesis because it implies that the banks' return ratios are more affected by the market concentration and monopolistic benefits than by the market share or the competitiveness gained by efforts to cut costs.

- Variable LOASS is not statistically significant when its coefficient is positive in model (3) and negative in model (4). Thus, its impacts are not analyzed.

\section{CONCLUSION AND RECOMMENDATIONS}

\section{a. Conclusion:}

Both models (3) and (4) support the SCP hypothesis which states that the market concentration, instead of market share, is the factor that impacts positively on the bank performance through ROAA and ROAE. Besides those two variables, the remaining ones impacting on the performance of Vietnam's commercial banks comprise the size of the banks, ownership, the ratio of deposit to total assets and the inflation rate. This implies the larger the bank size, the higher the banks' business performance, and in reverse, the higher the ratio of deposit to total assets and the inflation rate, the lower the banks' profitability ratio. Moreover, the results also indicate that joint-stock commercial banks are more efficient than state-owned rivals.

\section{b. Recommendations:}

The results allow suggestions of the following policy implications:

- In Vietnam's commercial banking system, the market concentration produces positive impacts on the rate of return of the banks. To improve their business performance and sustainable development, therefore, the SBV should encourage the weak and small banks to revise their business plans and management machineries.

If banks decide to restructure by merger and acquisition, the SBV should make a specific schedule for them, and carefully consider the feasibility of their restructuring plans by making data of each bank transparent. The restructuring must be in 
accordance with Article 18 and 19 of Competition Law, requiring that the combined market share of the banks may not larger than 50\%, except for the case in which one or more involved parties face a danger of being dissolved or declared bankrupt. This solution aims to help domestic banks improve their ability to survive and develop when facing foreign competition and upheavals in the economy.

- Government should reduce its controls over state-owned commercial banks by selling its shares to strategic investors and state-owned commercial banks should have plans to choose strategic investors and submit them for government's consideration and approval. These strategic investors must meet strict requirements in terms of financial strength and managerial skills to help the state-owned banks develop strongly and play well their leading roles in the banking system in Vietnam.

- The banks should be aware of the importance of the bank size to business performance and sustainable development. Then, every bank needs to find strategic investors in order to increase its capital by issuing more shares and attract investments from foreign strategic investors. However, the proportion of capital allowed to be held by foreign investors in Vietnam's commercial banks now is not attractive to major strategic investors. To carry out quickly and effectively the restructuring, therefore, government and Securities Commission need consider expanding the ownership ratio of foreign investors in Vietnam's commercial banks.

- The joint-stock commercial banks should plan a specific schedule for listing on the Stock Exchange to raise more funds. Listed banks are also considered as source of high-quality commodities for the stock market, especially when Vietnam Stock Exchanges join the ASEAN stock markets. This will be an opportunity for Vietnam's commercial banks to gain access to sources of capital by foreign investors as well as to publicize their images and expand their networks to Southeast Asia.

- The results also show that the inflation rate and the deposit-assets ratio have negative impacts on the banks' rate of return. As analyzed above, higher inflation in Vietnam leads to interest rate competition, which produces bad effects on the profitability of Vietnam's commercial banks. Thus, one of the solutions to the business performance of commercial banks is to keep inflation at a reasonable level, which requires a good combination of monetary and fiscal policies 


\section{References}

Bhatti, G. A. \& H. Hussain (2010), "Evidence on Structure Conduct Performance Hypothesis in Pakistani Commercial Banks", International Journal of Business and Management, 2, No.9, pp. 174-187.

Boyd, J. H., R. Levine \& B.D. Smith (2001), "The Impact of Inflation on Financial Sector Performance", Journal of Monetary Economics, 47, pp. 221-248.

Brozen, Y. (1982), Concentration, Merger and Public Policy, New York: Macmillan.

Brucker, E. (1970), “A Microeconomic Approach to Banking Competition”, Journal of Finance, pp. 1141.

Demsetz, H. (1973), "Industry Structure, Market Rivalry, and Public Policy", Journal of Law and Economics, 16(April), pp. 1-9.

Evanoff, D. D. \& D.I. Fortier (1988), "Reevaluation of the Structure-Conduct Performance Paradigm in Banking”, Journal of Financial Services Research, I(June), pp. 313-329.

García-Herrero, A., S. Gavilá \& D. Santabárbara (2009), "What Explains the Low Profitability of Chinese Banks?”, Journal of Banking and Finance, 33, pp. 2080-2092.

Hàn Phi \& Ngọc Tuyên (2012), "Hàng loạt ngân hàng sụt giảm lợi nhuận", available at http://www.baomoi.com/Hang-loat-ngan-hang-sut-giam-loi-nhuan/126/9627305.epi

Heggestad, A. A. \& J.J. Mingo (1977), "The Competitive Condition of US Banking Markets and the Impact of Structural Reform”, Journal of Finance, 32(June), pp. 649-661.

Lloyd-Williams, D. M., P. Molyneux \& J. Thornton (1994), "Market Structure and Performance in Spanish Banking”, Journal of Banking and Finance, 18, pp. 433-443.

Maudos, J. (1998), "Market Structure and Performance in Spanish Banking using a Direct Measure of Efficiency”, Applied Financial Economics, 8, pp. 191-200.

Mendes, V. \& J. Rebelo (2003), "Structure and Performance in the Portuguese Banking Industry in the Nineties", Portuguese Economic Journal, 2, pp. 53-68.

McGee, J. (1974), "Efficiency and Economies of Size" in H.J. Goldschmid et al. (eds) Industrial Concentration: The New Learning, Boston: Little, Brown, and Company, pp. 55-97.

Mirzaei, A., T. Moore \& G. Liu (2013), “Does Market Structure Matter on Banks' Profitability and Stability? Emerging vs. Advanced Economies”, Journal of Banking \& Finance, 37, pp. 2920 2937.

Molyneux, P., \& W. Forbes (1995), "Market Structure and Performance in European Banking", Applied Economics, 27, pp. 155-159.

Peltzman, S. (1977), "The Gains and Losses from Industrial Concentration", Journal of Law and Economics, 20(October), pp. 229-263. 
Phạm Huy Hùng (2008) “Ảnh hưởng của lạm phát đến hoạt động ngân hàng và các giải pháp kiềm chế lạm phát”, presented at the workshop "Lạm phát, các giải pháp kiềm chế lạm phát và hỗ trợ doanh nghiệp trong tình hình hiện nay”.

Podenda, Randall J. (1986), "Structure and Performance: Some Evidence from California Banking", Economic Review, pp. 5-17.

Rhoades, S. (1982), "Welfare Loss, Redistribution Effects, and Restriction of Output Due to Monopoly", Journal of Monetary Economics, 9, pp. 375-387.

Rose, P. S. \& D. R. Fraser (1976), “The Relationship Between Stability and Change in Market Structure: An Analysis of Bank Prices”, Journal of Industrial Economics, 24(June), pp. 251-266.

Samad, A. (2005), "Banking Structure and Performance: Evidence from Utah", Review of Business Research, 2, pp. 151-156.

Samad, A. (2007), "Market Structure, Conduct and Performance: Evidence from the Bangladesh Banking Industry", Journal of Asian Economics, 19, pp. 181-193.

Sathye, M. (2005), "Market Structure and Performance in Australian Banking”, Review of Accounting \& Finance, 4, No.2, pp. 107.

Smirlock, M. (1985), "Evidence on the (non) Relationship Between Concentration and Profitability in Banking", Journal of Money Credit and Banking, 17(February), pp. 69-83.

Smirlock, M., T. Gilligan \& W. Marshall (1984), “Tobin's Q and the Structure-Performance Relationship", The American Economic Review, 74, No. 5, pp. 1051-1060.

Spellman, L. J. (1981), “Commercial Banks and Profits of Savings and Loan Markets”, Journal of Bank Research, 12(Spring), pp. 32-36.

Thái Phương (2013), "Ngân hàng đã đến lúc phải cạnh tranh quyết liệt", available at http://kinhdoanh.vnexpress.net/tin-tuc/ebank/ngan-hang/ngan-hang-den-luc-phai-canh-tranhquyet-liet-2726338.html

Thanh Thanh Lan \& Bạch Hường (2013), "Nửa triệu tỉ đồng nợ xấu ngân hàng", available at http://kinhdoanh.vnexpress.net/tin-tuc/ebank/ngan-hang/nua-trieu-ty-dong-no-xau-ngan-hang2727453.html

Trương Quang Thông (2010), Phân tích hiệu năng hoạt động ngân hàng thuơng mại Việt Nam - Một nghiên cứu thục nghiệm mô hình SCP, Phương Đông Publisher. 